2018-05

\title{
Clinical Outcomes to Exercise Training in Type 1 Diabetes: A Systematic Review and Meta-Analysis.
}

Jewiss, D

http://hdl.handle.net/10026.1/11035

10.1016/j.diabres.2017.11.036

Diabetes Research and Clinical Practice

Elsevier

All content in PEARL is protected by copyright law. Author manuscripts are made available in accordance with publisher policies. Please cite only the published version using the details provided on the item record or document. In the absence of an open licence (e.g. Creative Commons), permissions for further reuse of content should be sought from the publisher or author. 


\section{Accepted Manuscript}

Clinical Outcomes to Exercise Training in Type 1 Diabetes: A Systematic Review and Meta-Analysis

D. Jewiss, C. Ostman, N. King, N.A. Smart

PII:

S0168-8227(17)31108-7

DOI: https://doi.org/10.1016/j.diabres.2017.11.036

Reference:

DIAB 7156

To appear in: $\quad$ Diabetes Research and Clinical Practice

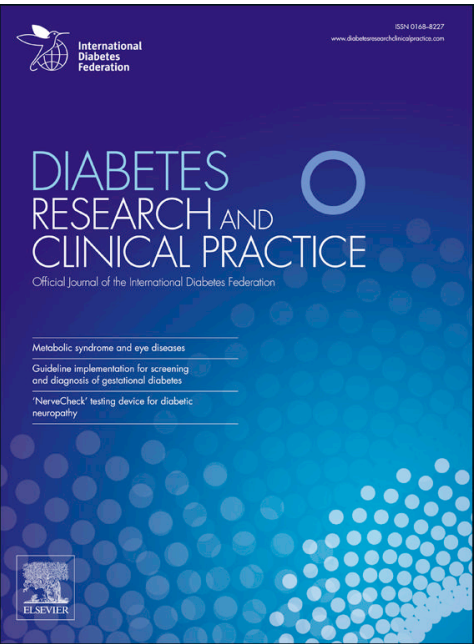

Received Date: $\quad 10$ July 2017

Revised Date: $\quad 25$ August 2017

Accepted Date: $\quad 28$ November 2017

Please cite this article as: D. Jewiss, C. Ostman, N. King, N.A. Smart, Clinical Outcomes to Exercise Training in Type 1 Diabetes: A Systematic Review and Meta-Analysis, Diabetes Research and Clinical Practice (2017), doi: https://doi.org/10.1016/j.diabres.2017.11.036

This is a PDF file of an unedited manuscript that has been accepted for publication. As a service to our customers we are providing this early version of the manuscript. The manuscript will undergo copyediting, typesetting, and review of the resulting proof before it is published in its final form. Please note that during the production process errors may be discovered which could affect the content, and all legal disclaimers that apply to the journal pertain. 
Clinical Outcomes to Exercise Training in Type 1 Diabetes: A Systematic Review and Meta-Analysis.

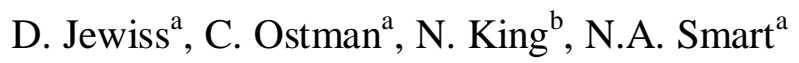

${ }^{a}$ Schools of Rural Medicine and Science and Technology,

University of New England, Armidale, NSW 2351, Australia

${ }^{b}$ School of Biomedical and Healthcare Sciences, Plymouth University Peninsula Schools of Medicine and Dentistry, Plymouth University, Plymouth, PL4 8AA, UK

Running head: Exercise training in type I diabetes: meta-analysis

Funding: This research did not receive any specific grant from funding agencies in the public, commercial, or not-for-profit sectors.

Conflicts of interest: None declared

Word count: 5289

Address for correspondence:

Professor Neil A Smart, School of Science and Technology, University of New England, Armidale, NSW 2351. Australia.

Email: nsmart2@une.edu.au 


\section{ABSTRACT}

Aims To establish the relationship between exercise training and clinical outcomes in people with type I diabetes.

Methods Studies were identified through a MEDLINE search strategy, Cochrane Controlled Trials Registry, CINAHL, SPORTDiscus and Science Citation Index. The search strategy included a mix of key concepts related to exercise training; type 1 diabetes; glycaemic control for trials of exercise training in people with type 1 diabetes. Searches were limited to prospective randomized or controlled trials of exercise training in humans with type 1 diabetes lasting 12 weeks or more.

Results In exercised adults there were significant improvements in body mass Mean Difference (MD): $-2.20 \mathrm{~kg}, 95 \%$ Confidence Interval (CI) $-3.79-0.61, \mathrm{p}=0.007$; body mass index (BMI) MD: $-0.39 \mathrm{~kg} / \mathrm{m}^{2}, 95 \%$ CI -0.75 -0.02, $\mathrm{p}=0.04$; Peak $\mathrm{VO}_{2} \mathrm{MD}: 4.08 \mathrm{ml} / \mathrm{kg} / \mathrm{min}$, 95\% CI 2.18 5.98, p<0.0001; and, low-density lipoprotein cholesterol (LDL) MD: -0.21 $\mathrm{mmol} / \mathrm{L}, 95 \% \mathrm{CI}-0.33-0.08, \mathrm{p}=0.002$. In exercised children there were significant improvements in insulin dose MD: $-0.23 \mathrm{IU} / \mathrm{kg}, 95 \% \mathrm{CI}-0.37-0.09, \mathrm{p}=0.002$; waist circumference MD: $-5.40 \mathrm{~cm}, 95 \%$ CI $-8.45-2.35$, p=0.0005; LDL MD: $-0.31 \mathrm{mmol} / \mathrm{L}, 95 \%$ CI $-0.55-0.06, \mathrm{p}=0.02$; and, triglycerides MD: $-0.21 \mathrm{mmol} / \mathrm{L}, 95 \% \mathrm{CI}-0.42-0.0, \mathrm{p}=0.04$. There were no significant changes in glycosylated haemoglobin $(\mathrm{HbA} 1 \mathrm{C} \%)$, fasting blood glucose, resting heart rate, resting systolic blood pressure or high density lipoproteins in either group.

Conclusions Exercise training improves some markers of type 1 diabetes severity; particularly body mass, $\mathrm{BMI}$, Peak $\mathrm{VO}_{2}$ and LDL in adults and insulin dose, waist circumference, LDL and triglycerides in children.

\section{Keywords}


Exercise Training, Meta-Analysis, Type I diabetes

\author{
Abbreviations \\ Body Mass Index (BMI) \\ CI - Confidence Interval \\ HDL - High Density Lipoproteins \\ LDL - Low Density Lipoproteins \\ HbA1C\% - Glycosylated Hemoglobin \\ $\% \mathbf{H R}_{\max }$ - Heart Rate Peak \\ $\% \mathrm{VO}_{2}$ Peak - Percentage of Peak Oxygen Uptake \\ MD - Mean Difference
}

\title{
INTRODUCTION
}

The clinically beneficial effects of lifestyle interventions have been shown in meta-analyses in people with type II diabetes [1]. Substantial pooled data has demonstrated improvements in peak $\mathrm{VO}_{2}$ [2] and glycaemic control [3] in individuals with type II diabetes. In the general population, high intensity interval training has been shown to be more effective in regulating glucose than continuous training at lower intensity [4]. Moreover, high intensity exercise training has been shown to be superior to lower intensity exercise for improving cardiorespiratory fitness (peak $\mathrm{VO}_{2}$ ) in heart failure patients [5-7]. Evidence of beneficial effects of regular exercise training is sparse for people with Type I Diabetes (T1D).

While few trials of exercise training in T1D exits, it has been demonstrated that increased physical activity is associated with an increased life expectancy and a lower risk of 
complications in these patients [8]. More alarmingly an estimated $60 \%$ of adults with T1D do not undertake the recommended 150 minutes of weekly levels of physical activity at moderate (50-70\% HRmax) to vigorous (>70\% HRmax) intensity [9]. However, the clinical implications of these guidelines are contentious and their effect on clinical outcomes are yet to be established.

Poor compliance rate may be at least be partially explained by fear of an induced hypoglycaemic episode and fitness levels [10]. While it has been shown that educational interventions improve the associated fear of exercise induced hypoglycaemic event, no appropriate evidence addresses the efficacy of the current recommendations and their relationship to the clinical outcomes [10]. With T1D affecting adult, adolescent and paediatric groups, the recommendations for children and adults in terms of physical activity are very similar. We focused our work on establishing the clinical efficacy of the recommendation for physical activity in all patients with Type 1 Diabetes.

We conducted a systematic analysis of all clinical randomized, controlled, aerobic exercise training trials in people with type I diabetes. We aimed, via systematic review, to establish the relationship between physical activity and its effect on clinical markers of glycaemic control and cardiorespiratory fitness. Secondly, we wished to establish if exercise training program parameters affected the size of change in clinical outcome measures. Finally, we examined if our findings aligned with the current recommendations for physical activity.

\section{MATERIALS AND METHODS}

\section{Search Strategy}


Studies were identified through a MEDLINE search strategy (1985 to Aug 4, 2016), Cochrane Controlled Trials Registry (1966 to Aug 4, 2016), CINAHL, SPORTDiscus and Science Citation Index. The search strategy included a mix of MeSH and free text terms for the key concepts related to exercise training, type 1 diabetes and glycaemic control for clinical trials of exercise training in people with type 1 diabetes (see PubMed search strategy in Supplementary file). We considered all types of physical training. Studies were included if patients exhibited a diagnosis of type 1 diabetes. Searches were limited to prospective randomized or controlled trials of exercise training in humans, lasting 12 weeks or more. No restrictions were placed on the year, or language, of publication. Reference list of papers and latest editions of relevant journals which were not available online were scrutinised for new references. Full articles were read and assessed by two reviewers (DJ and CO) for relevance and study eligibility. Disagreements on methodology were resolved by discussion, a third reviewer (NS) adjudicated over any disputes. Study authors were contacted and requested to provide further data if required.

\section{Study selection}

Included studies were randomized controlled trials of exercise training in people with type 1 diabetes. All published studies included in this systematic review were comparisons between intervention groups and a sedentary control.

In addition to the studies identified through database searching, reference lists of identified studies were scrutinized. Only the principal study with the greatest number of subjects was included where multiple publications existed from the same dataset. After initial screening we removed over-lapping, duplicates, duplicate data and irrelevant articles such as editorials and discussion papers that did not match the inclusion criteria. We excluded studies where 
the control group received additional intervention or did not have type 1 diabetes, nonrelevant studies; and those reporting only acute exercise testing responses. We excluded studies from specific analyses if incomplete data was reported and the authors did not respond to our requests to provide missing data.

\section{Outcomes measures}

We recorded the following data; percentage change in $\mathrm{HbA1c} \%$, BMI, body mass, Waist Circumference, peak $\mathrm{VO}_{2}$, resting heart rate, resting systolic blood pressure, fasting blood glucose, low density lipoproteins (LDL), high density lipoproteins (HDL), triglycerides and daily insulin dose. We also recorded exercise training frequency, intensity, duration persession, length of exercise program, participant exercise adherence and completion rates.

\section{Data Synthesis}

From extracted data we calculated patient-hours of exercise training, mean difference change in outcome measures and medical events.

\section{Assessment of study quality}

We assessed study quality with regard to: eligibility criteria specified, random allocation of participants, allocation concealed, similarity groups at baseline, assessors blinded, outcome measures assessed in $85 \%$ of participants and intention to treat analysis. The study quality was assessed according to the validated TESTex scale which has a maximum score of 15 [11].

\section{Data Synthesis}


Revman 5.3 (Nordic Cochrane Centre, Denmark) was used to complete the meta-analysis and generate forest plots. Pooled data are presented as mean differences. A minimum of three intervention groups was required for forest plots. Some studies used more than one intervention group, but the same people were only represented once in our forest plots.

Meta-analyses were completed for continuous data by using the change in the mean and standard deviation of outcome measures. It is an accepted practice to only use post intervention data for meta-analysis but this method assumes that random allocation of participants always creates intervention groups matched at baseline for age, disease severity etc. Change in post intervention mean was calculated by subtracting baseline from post intervention values. Data required was either (i) $95 \%$ confidence interval data for pre-post intervention change for each group or when this was unavailable (ii) actual $p$ values for prepost intervention change for each group or if only the level of statistical significance was available (iii) we used default $\mathrm{p}$ values e.g. $\mathrm{p}<0.05$ becomes $\mathrm{p}=0.049, \mathrm{p}<0.01$ becomes $\mathrm{P}=0.0099$ and $\mathrm{p}=$ not significant becomes $\mathrm{p}=0.05$.

Where appropriate data was divided into subgroups according to adults and children (under 18 years); and, pre and post 2000 studies. This was considered important because of developmental changes to insulin formulations and insulin delivery technologies have evolved a great deal over the past two decades. We believe these differences may lead to differences in key parameters such as peak $\mathrm{VO}_{2}$ and because of possible chronological variations in the technique used to measure some of the variables e.g. peak $\mathrm{VO}_{2}$. In many cases there was insufficient studies/intervention groups to facilitate a complete analysis of all the experimental groups.

\section{Heterogeneity}


Heterogeneity was quantified using the $\mathrm{I}^{2}$ test [12], as it does not inherently depend upon the number of studies considered. $\mathrm{I}^{2}$ values range from $0 \%$ (homogeneity) to $100 \%$ (greater heterogeneity); a $C I$ that does not include $0 \%$ indicates that the hypothesis of homogeneity is rejected, and an inference of heterogeneity is merited [12]. A random effects model was used throughout.

\section{Publication Bias}

Egger plots [13] were provided to assess the risk of publication bias (see supplementary files).

\section{RESULTS}

Our initial search identified 36 manuscripts. After removal of duplicates, 33 studies remained, of which 14 were not randomised controlled trials. Out of the remaining 19 studies, two were excluded due to a lack of proper randomisation, 2 were excluded due to a control group consisting of those without diabetes, and another study was excluded for a nonexercise intervention. This left 14 included studies [10, 14-27] for analysis. The search details are provided in the CONSORT Statement, Figure 1.

Our analysis of the 15 studies (16 intervention groups) totalled 596 participants; 360 from exercise groups and 236 from control groups. Five of the studies involved adults and 6 of the studies were completed before 2000. The studies contain data from 9,251 patient-hours of exercise training. Studies ranged in duration from 12-26 weeks (average 18.7 weeks, median 16 weeks), and 1-7 weekly exercise sessions (median =3) and session duration ranged from 20-120 minutes (median $=47.5$ ). Table 1 . Summarizes the details of the included studies. 


\section{Meta-Analyses}

All forest plots can be seen in the supplementary file.

\section{HbA1C\%}

Eleven intervention groups provided data on $\mathrm{HbA} 1 \mathrm{C} \%$ of which 4 intervention groups were in adults with the remainder in children and 4 studies were carried out prior to 2000. Results show that there was no significant difference between exercise and control for either adults MD: $-0.08 \%, 95 \% \mathrm{CI}:-0.38,0.22 ; \mathrm{p}=0.6\left(\mathrm{Chi}^{2}=13.96, \mathrm{df}=3, \mathrm{p}=0.003 ; \mathrm{I}^{2}=79 \%\right)$; or, children MD: $-0.27 \%, 95 \%$ CI $-0.73,0.19 ; p=0.25\left(\mathrm{Chi}^{2}=22.97, \mathrm{df}=6, \mathrm{p}=0.0008 ; \mathrm{I}^{2}=\right.$ 74\%). There was also no significant difference between studies that were performed post$2000 \mathrm{MD}-0.11 \%, 95 \%$ CI $-0.37,0.16 ; \mathrm{p}=0.43\left(\mathrm{Chi}^{2}=32.79, \mathrm{df}=6, \mathrm{p}=0.0001 ; \mathrm{I}^{2}=82 \%\right)$; and, studies that were performed pre-2000 MD: $-0.15 \%, 95 \% \mathrm{CI}-0.76,0.46 ; \mathrm{p}=0.62\left(\mathrm{Chi}^{2}=\right.$ $6.18, \mathrm{df}=3, \mathrm{p}=0.10 ; \mathrm{I}^{2}=51 \%$ ).

\section{Total daily insulin dose (IU/kg)}

There was insufficient studies to pool data for total daily insulin dose in adults and in pre2000 studies. Four intervention groups studied this parameter in children, which showed that exercise significantly lowered the total daily insulin dose MD: -0.23 IU/kg, 95\% CI -0.37 $0.09 ; \mathrm{p}=0.002\left(\mathrm{Chi}^{2}=23.48, \mathrm{df}=3, \mathrm{p}<0.0001 ; \mathrm{I}^{2}=87 \%\right)$. A similar significantly lowering effect with exercise was measured in the 6 post-2000 intervention groups, where MD: -0.16 , $95 \%$ CI $-0.26,-0.05 ; \mathrm{p}=0.003\left(\mathrm{Chi}^{2}=84.46, \mathrm{df}=5, \mathrm{p}<00001 ; \mathrm{I}^{2}=94 \%\right)$.

\section{Fasting blood glucose in children (mmol/L)}


There was only sufficient intervention groups (3) to perform data pooling on fasting blood glucose in children. Results show that there was no significant effect of exercise MD: -0.71 $\mathrm{mmol} / \mathrm{L}, 95 \% \mathrm{CI}-1.94,0.52 ; \mathrm{p}=0.26\left(\mathrm{Chi}^{2}=19.18, \mathrm{df}=2, \mathrm{p}<0.0001 ; \mathrm{I}^{2}=90 \%\right)$.

\section{Body mass (kg)}

Sufficient data was available to perform data pooling in adults (3 intervention groups), children (4 intervention groups) and post-2000 (5 intervention groups) studies. Results show that exercise significantly reduced body mass in adults MD: $-2.20 \mathrm{~kg}, 95 \% \mathrm{CI}-3.79,-0.61 ; \mathrm{p}$ $=0.007\left(\mathrm{Chi}^{2}=5.12, \mathrm{df}=2, \mathrm{p}=0.08 ; \mathrm{I}^{2}=61 \%\right)$. In contrast, exercise significantly increased body mass in children MD: $0.95 \mathrm{~kg}, 95 \%$ CI $0.17,1.73 ; \mathrm{p}=0.02\left(\mathrm{Chi}^{2}=2.12, \mathrm{df}=3, \mathrm{p}=\right.$ $0.55, \mathrm{I}^{2}=0 \%$ ). Exercise did not significantly affect body mass in post-2000 studies MD: $0.54,95 \% \mathrm{CI}=-2.1,1.02 ; \mathrm{p}=0.5\left(\mathrm{Chi}^{2}=17.95, \mathrm{df}=4, \mathrm{p}=0.001 ; \mathrm{I}^{2}=78 \%\right)$.

\section{$\operatorname{BMI}\left(\mathrm{kg} / \mathrm{m}^{2}\right)$}

Sufficient data was available to perform data pooling in adults (3 intervention groups), children (3 intervention groups) and post-2000 (6 intervention groups) studies. Results show that exercise significantly reduced BMI in adults MD: $-0.39 \mathrm{~kg} / \mathrm{m}^{2}, 95 \% \mathrm{CI}-0.75,-0.02 ; \mathrm{p}=$ $0.04\left(\mathrm{Chi}^{2}=7.54, \mathrm{df}=2, \mathrm{p}=0.02 ; \mathrm{I}^{2}=73 \%\right)$; but not in children MD: $0.29 \mathrm{~kg} / \mathrm{m}^{2}, 95 \% \mathrm{CI}-$ 0.03, 0.61; $\mathrm{p}=0.07\left(\mathrm{Chi}^{2}=1.92, \mathrm{df}=2, \mathrm{p}=0.38 ; \mathrm{I}^{2}=0 \%\right)$. Exercise did not exert any significant effect in post-2000 studies MD: $-0.11 \mathrm{~kg} / \mathrm{m}^{2}, 95 \% \mathrm{CI}-0.43,0.21 ; \mathrm{p}=0.5\left(\mathrm{Chi}^{2}=\right.$ $\left.18.83, \mathrm{df}=5, \mathrm{p}=0.002 ; \mathrm{I}^{2}=73 \%\right)$.

\section{Waist circumference in children $(\mathrm{cm})$}

Three intervention groups reported waist circumference in children and in post-2000 studies. In children, results show that exercise significantly reduced waist circumference MD: -5.4 
$\mathrm{cm}, 95 \% \mathrm{CI}-8.45,-2.35 ; \mathrm{p}=0.0005\left(\mathrm{Chi}^{2}=92.45, \mathrm{df}=2 ; \mathrm{p}<0.00001 ; \mathrm{I}^{2}=98 \%\right)$. There was insufficient data to perform pooling for adults and pre-2000 studies.

\section{Peak $\mathrm{VO}_{2}(\mathrm{ml} / \mathrm{kg} / \mathrm{min})$}

Peak $\mathrm{VO}_{2}$ was reported in 4 adult studies and 3 studies on children. Results show that exercise significantly increased peak $\mathrm{VO}_{2}$ in adults $\mathrm{MD}: 4.08 \mathrm{ml} . \mathrm{kg}^{-1} . / \mathrm{min}^{-1}, 95 \% \mathrm{CI} 2.18$, 5.98; $\mathrm{p}<0.0001\left(\mathrm{Chi}^{2}=4.88, \mathrm{df}=3, \mathrm{p}=0.18 ; \mathrm{I}^{2}=39 \%\right) ;$ but, not in children MD: 1.95 $\mathrm{ml} . \mathrm{kg}^{-1} . / \mathrm{min}^{-1}, 95 \%$ CI $0.04,3.85 ; \mathrm{p}=0.05\left(\mathrm{Chi}^{2}=0.96, \mathrm{df}=2, \mathrm{p}=0.62 ; \mathrm{I}^{2}=0 \%\right)$. Four pre2000 and 3 post-2000 studies reported peak $\mathrm{VO}_{2}$. Results show exercise significantly increased peak $\mathrm{VO}_{2}$ in both pre-2000 studies MD: $2.22 \mathrm{ml} . \mathrm{kg}^{-1} . / \mathrm{min}^{-1}, 95 \%$ CI $0.88,3.57 ; \mathrm{p}=$ $0.001\left(\mathrm{Chi}^{2}=1.13, \mathrm{df}=3, \mathrm{p}=0.77 ; \mathrm{I}^{2}=0 \%\right.$; and post-2000 studies MD: $3.1 \mathrm{ml} . \mathrm{kg}^{-1} . / \mathrm{min}^{-1}$, $95 \%$ CI 0.29, 5.91; $\mathrm{p}=0.03\left(\mathrm{Chi}^{2}=3.47, \mathrm{df}=2 ; \mathrm{p}=0.18 ; \mathrm{I}^{2}=42 \%\right)$.

\section{Resting heart rate in adults (bpm)}

There were insufficient data for pooling in children, pre-2000 and post-2000 studies regarding resting heart rate. Three studies reported resting heart rate in adults. Results show there was no significant difference in exercise compared to control MD: $-4.11 \mathrm{bpm}, 95 \% \mathrm{CI}$ 9.01, 0.8; $\mathrm{p}=0.1\left(\mathrm{Chi}^{2}=7.24, \mathrm{df}=2, \mathrm{p}=0.03 ; \mathrm{I}^{2}=72 \%\right)$.

\section{Resting systolic blood pressure in post-2000 studies (mmHg)}

There were insufficient data for pooling in adults, children and pre-2000 studies. Results show that there was no significant difference in exercise compared to control MD: -3.89 $\mathrm{mmHg}, 95 \% \mathrm{CI}-11.61,3.82 ; \mathrm{p}=0.32\left(\mathrm{Chi}^{2}=0.2, \mathrm{df}=2, \mathrm{p}=0.91 ; \mathrm{I}^{2}=0 \%\right)$.

\section{LDL (mmol/L)}


LDL was reported in 4 adults studies and in 3 (4 intervention groups) studies in children. Exercise significantly reduced LDL in both adults MD: $-0.21 \mathrm{mmol} / \mathrm{L}, 95 \% \mathrm{CI}-0.33,-0.08 ; \mathrm{p}$ $=0.002\left(\mathrm{Chi}^{2}=1.08, \mathrm{df}=3, \mathrm{p}=0.78 ; \mathrm{I}^{2}=0 \%\right) ;$ and, in children MD: $-0.31 \mathrm{mmol} / \mathrm{L}, 95 \% \mathrm{CI}$ $-0.55,-0.06 ; \mathrm{p}=0.02\left(\mathrm{Chi}^{2}=8.75, \mathrm{df}=3, \mathrm{p}=0.03 ; \mathrm{I}^{2}=66 \%\right)$. LDL was also reported in 6 intervention groups post-2000. Results show that exercise led to a significant reduction in LDL MD: $-0.24 \mathrm{mmol} / \mathrm{L}, 95 \% \mathrm{CI}-0.39,-0.09 ; \mathrm{p}=0.002\left(\mathrm{Chi}^{2}=9.23, \mathrm{df}=5, \mathrm{p}=0.10 ; \mathrm{I}^{2}=\right.$ $48 \%)$.

\section{HDL $(\mathbf{m m o l} / \mathrm{L})$}

HDL was reported in 4 adults studies and 3 (4 intervention groups) studies in children.

Exercise did not affect the plasma HDL concentration in either adults MD: $0.01 \mathrm{mmol} / \mathrm{L}$, 95\% CI -0.08, 0.10; $\mathrm{p}=0.86\left(\mathrm{Chi}^{2}=10.86, \mathrm{df}=3, \mathrm{p}=0.01 ; \mathrm{I}^{2}=72 \%\right)$; or children MD: 0.15 $\mathrm{mmol} / \mathrm{L}, 95 \% \mathrm{CI}-0.07,0.37 ; \mathrm{p}=0.17\left(\mathrm{Chi}^{2}=22.13, \mathrm{df}=3, \mathrm{p}<0.0001 ; \mathrm{I}^{2}=86 \%\right)$. HDL was also reported in 5 (6 intervention groups) post 2000 studies, where exercise also did not affect the plasma HDL concentration MD: $0.1 \mathrm{mmol} / \mathrm{L}, 95 \% \mathrm{CI}-0.07,0.28 ; \mathrm{p}=0.26\left(\mathrm{Chi}^{2}=48.35\right.$, df $\left.=5, \mathrm{p}<0.00001 ; \mathrm{I}^{2}=90 \%\right)$.

\section{Triglycerides $(\mathbf{m m o l} / \mathrm{L})$}

Triglycerides were reported in 4 adult studies and 3 (4 intervention groups) studies in children. Exercise did not affect triglycerides in adults MD: $-0.1 \mathrm{mmol} / \mathrm{L}, 95 \% \mathrm{CI}-0.31,0.11$; $\mathrm{p}=0.33\left(\mathrm{Chi}^{2}=26.27, \mathrm{df}=3, \mathrm{p}<0.00001 ; \mathrm{I}^{2}=89 \%\right)$. In contrast, exercise significantly reduced triglycerides in children MD: $-0.21 \mathrm{mmol} / \mathrm{L}, 95 \% \mathrm{CI}-0.42,-0.01 ; \mathrm{p}=0.04\left(\mathrm{Chi}^{2}=\right.$ $\left.649.47, \mathrm{df}=3, \mathrm{p}<0.00001 ; \mathrm{I}^{2}=100 \%\right)$. In addition, triglycerides were measured in $5(6$ intervention groups) post 2000 studies. The MD was $-0.25 \mathrm{mmol} / \mathrm{L}, 95 \% \mathrm{CI}-0.43,-0.08 ; \mathrm{p}=$ $0.004\left(\mathrm{Chi}^{2}=649.95, \mathrm{df}=5, \mathrm{p}<0.00001 ; \mathrm{I}^{2}=99 \%\right)$. 


\section{Effect of Exercise Time on Selected Outcome Measures}

Table 2 shows changes in outcome measures stratified by weekly exercise time. Overall the response was varied with regard to weekly exercise time.

\section{Study Quality}

The TESTEX scale of study quality revealed a median score of 10 (out of a possible 15).

Study quality items that were not exhibited by more than $50 \%$ of studies were, assessor blinding ( 0 studies), intention to treat analyses ( 0 studies), relative exercise intensity review (6 studies) and activity monitoring of the control (non-exercise) groups (0 studies) (See Table $3)$.

\section{DISCUSSION}

Our work is the first to conduct a data pooling analysis of the effects of exercise training and associated moderator variables on clinical markers of type I diabetes control. In children our analyses showed improvements in total daily insulin dose, waist circumference, LDL and triglycerides. In adults there were improvements in body mass, $\mathrm{BMI}$, peak $\mathrm{VO}_{2}, \mathrm{LDL}$ and triglycerides. Peak $\mathrm{VO}_{2}$ was also improved in studies carried out both pre- and post-2000, whilst LDL and triglycerides decreased in post 2000 studies. There remains insufficient published data to establish the moderating effect of exercise program duration for most of the reported outcome measures, however it is likely that exercise program duration has a moderating role.

Hba1C\% did not show a significant change with exercise training. Given that the median duration of included studies was 13 weeks, which is a similar duration to the life of a red 
blood cell, it is possible that only partial changes in $\mathrm{HbA} 1 \mathrm{c} \%$ via exercise training are possible in such a short timeframe. The pre-enrolment physical activity levels of the participants in many of the included studies were unknown, therefore the expected benefit is difficult to ascertain. However, the importance of sustained lifestyle changes to affect health improvements should be reinforced as previous systematic reviews have suggested sedentary behaviour in youths with Type 1 diabetes [28, 29].

Interestingly, exercise led to a significantly reduced body mass in adults, but a significantly increased body mass in children. A similarly increasing effect on body mass with improved hepatic insulin sensitivity has been reported in obese children in response to resistance training [30]. In that study the increased body mass was associated with increased lean body mass [30]. An increase in muscle mass may also explain the weight gain in studies conducted on children in our analysis, particularly since we also showed a decreased waist circumference in the studies conducted on children and a reduced total daily insulin dose. A small, pooled analysis from 2014 suggests equivocal findings with respect to insulin dose [31].

Our serum LDL results showed improvement in both adults and children with exercise. A recent meta-analysis in participants with type 2 diabetes mellitus reported no change in serum LDL [32], whilst an older meta-analysis reporting on apparently healthy elderly participants had results favouring positive changes in LDL [33]. In contrast, a non-randomised controlled trial has shown a reduction in LDL after exercise in children with type 1 diabetes [34].

The change in Peak $\mathrm{VO}_{2}$ in adults was in the order of 0.8 METs and this moderate effect is to be expected in a known chronic disease group. Our analyses were however unable to identify 
that at least 100 minutes of weekly activity is optimal for change in peak $\mathrm{VO}_{2}$. Previous work has shown that intensity is the primary stimulus for improved cardiorespiratory fitness in people with cardiac disease [6]. One may expect intuitively that increasing exercise program duration would produce greater improvements in peak $\mathrm{VO}_{2}$. It is therefore perhaps surprising that studies comparing shorter and longer exercise program durations have produced nonuniform effects on peak $\mathrm{VO}_{2}[5,6,35]$. The likely explanation for this phenomenon is that it may be more difficult to get patients to continue to adhere to an exercise program in the longer term.

Our sub-analyses produced conflicting results with respect to weekly exercise time, the more time exercising, the better the effect on glycaemic control, however the less time, the better effect on the lipids. It is remarkable that the exercise guidelines for type II diabetes were one of the first to offer a sliding exercise prescription scale, based upon the manipulation of intensity and weekly duration in order to keep work volume relatively constant [36]. These guidelines suggest 270 weekly minutes of moderate intensity exercise but only 90 minutes of vigorous intensity activity. Our work suggests a varied response to weekly exercise duration, so the existence of a two-tiered exercise prescription could be related to total work, or energy expended. Energy expenditure is the product of exercise duration, intensity and frequency. We were unable to calculate energy expenditure in a sufficient number of the included studies to shed more light on this.

\section{Limitations}

A major limitation of this work was that considerable heterogeneity meant that data pooling was unjustified in a number of meta-analyses. We systematically attempted to identify reasons for heterogeneity by grouping studies according to similarities in interventions and 
exercise programs. We were able to reduce heterogeneity somewhat by limiting data pooling to studies that did not use concurrent dietary interventions. For several of the studies included in this meta-analysis we were unable to determine if medications held steady across the study groups. Even if we knew of medication changes, we would need to assess individual patient data for this to be meaningful. We are therefore unable to gauge the extent to which the observed changes were attributable to any medication changes. A similar issue is true of subjects who exhibited low or high resting heart rate, blood pressure and body mass as at group-level, and not patient level, data analysis we are unable to make adjustments to analyses. The exercise training programs varied greatly between studies with respect to exercise intensity, duration, frequency and modality. The normal distribution of the Egger plots evidenced minimal risk of publication bias.

Measures of lean and fat mass would have shed more light onto the role that body composition plays in improving glycaemic control through exercise. We would like to have conducted more moderator variable analyses but limited extracted data precluded this. We were only able to consider program duration, and high/vigorous versus low/moderate exercise intensity sub-analyses.

\section{Conclusions}

Exercise training improves some markers of type 1 diabetes severity; particularly body mass, BMI, Peak $\mathrm{VO}_{2}$ and LDL in adults and insulin dose, waist circumference, LDL and triglycerides in children.Our analysis support existing guidelines that for those who can tolerate it, we were unable to determine if exercise at any intensity offered superior benefits.

\section{Acknowledgements}


None

References

[1] Chen, L., Pei, J. H., Kuang, J., Chen, H. M., Chen, Z., Li, Z. W. and Yang, H. Z. Effect of lifestyle intervention in patients with type 2 diabetes: a meta-analysis. Metabolism, 64, 2 (Feb 2015), 338-347.

[2] Boule, N. G., Kenny, G. P., Haddad, E., Wells, G. A. and Sigal, R. J. Meta-analysis of the effect of structured exercise training on cardiorespiratory fitness in Type 2 diabetes mellitus. Diabetologia, 46, 8 (Aug 2003), 1071-1081.

[3] Snowling, N. J. and Hopkins, W. G. Effects of different modes of exercise training on glucose control and risk factors for complications in type 2 diabetic patients: a meta-analysis. Diabetes Care, 29, 11 (Nov 2006), 2518-2527.

[4] Jelleyman, C., Yates, T., O'Donovan, G., Gray, L. J., King, J. A., Khunti, K. and Davies, M. J. The effects of high-intensity interval training on glucose regulation and insulin resistance: a meta-analysis. Obes Rev, 16, 11 (Nov 2015), 942-961.

[5] Ismail, H., McFarlane, J. R., Dieberg, G. and Smart, N. A. Exercise training program characteristics and magnitude of change in functional capacity of heart failure patients. Int $J$ Cardiol, 171, 1 (Jan 15 2014), 62-65.

[6] Ismail, H., McFarlane, J. R., Nojoumian, A. H., Dieberg, G. and Smart, N. A. Clinical outcomes and cardiovascular responses to different exercise training intensities in patients with heart failure: a systematic review and meta-analysis. JACC. Heart failure, 1, 6 (Dec 2013), 514-522.

[7] Jewiss, D., Ostman, C. and Smart, N. A. The effect of resistance training on clinical outcomes in heart failure: A systematic review and meta-analysis. Int J Cardiol, 221 (Jul 5 2016), 674-681. 
[8] Tielemans, S. M., Soedamah-Muthu, S. S., De Neve, M., Toeller, M., Chaturvedi, N., Fuller, J. H. and Stamatakis, E. Association of physical activity with all-cause mortality and incident and prevalent cardiovascular disease among patients with type 1 diabetes: the EURODIAB Prospective Complications Study. Diabetologia, 56, 1 (Jan 2013), 82-91. [9] Plotnikoff, R. C., Taylor, L. M., Wilson, P. M., Courneya, K. S., Sigal, R. J., Birkett, N., Raine, K. and Svenson, L. W. Factors associated with physical activity in Canadian adults with diabetes. Med Sci Sports Exerc, 38, 8 (Aug 2006), 1526-1534.

[10] Brazeau, A. S., Rabasa-Lhoret, R., Strychar, I. and Mircescu, H. Barriers to physical activity among patients with type 1 diabetes. Diabetes Care, 31, 11 (Nov 2008), 2108-2109. [11] Smart, N. A., Waldron, M., Ismail, H., Giallauria, F., Vigorito, C., Cornelissen, V. and Dieberg, G. Validation of a new tool for the assessment of study quality and reporting in exercise training studies: TESTEX. International journal of evidence-based healthcare, 13, 1 (Mar 2015), 9-18.

[12] Higgins JPT, T. S., Deeks JJ, Altman DG. Measuring inconsistency in meta-analysis. British Medical Journal, 327, 7414 (2003), 557-560.

[13] Egger, M., Davey Smith, G., Schneider, M. and Minder, C. Bias in meta-analysis detected by a simple, graphical test. BMJ, 315, 7109 (Sep 13 1997), 629-634.

[14] Campaigne, B. N., Gilliam, T. B., Spencer, M. L., Lampman, R. M. and Schork, M. A. Effects of a physical activity program on metabolic control and cardiovascular fitness in children with insulin-dependent diabetes mellitus. Diabetes Care, 7, 1 (Jan-Feb 1984), 57-62. [15] Dahl-Jorgensen, K., Meen, H. D., Hanssen, K. F. and Aagenaes, O. The effect of exercise on diabetic control and hemoglobin A1 (HbA1) in children. Acta Paediatr Scand Suppl, 283 (1980), 53-56.

[16] D'Hooge, R., Hellinckx, T., Van Laethem, C., Stegen, S., De Schepper, J., Van Aken, S., Dewolf, D. and Calders, P. Influence of combined aerobic and resistance training on 
metabolic control, cardiovascular fitness and quality of life in adolescents with type 1 diabetes: a randomized controlled trial. Clinical rehabilitation, 25, 4 (Apr 2011), 349-359. [17] Fuchsjager-Mayrl, G., Pleiner, J., Wiesinger, G. F., Sieder, A. E., Quittan, M., Nuhr, M. J., Francesconi, C., Seit, H. P., Francesconi, M., Schmetterer, L. and Wolzt, M. Exercise training improves vascular endothelial function in patients with type 1 diabetes. Diabetes Care, 25, 10 (Oct 2002), 1795-1801.

[18] Heyman, E., Toutain, C., Delamarche, P., Berthon, P., Briard, D., Youssef, H., DeKerdanet, M., and Gratas-Delamarche, A.Exercise training and cardiovascular risk factors in type 1 diabetic adolescent girls. Pediatric Exercise Sci, 19, 408-419.

[19] Huttunen, N. P., Lankela, S. L., Knip, M., Lautala, P., Kaar, M. L., Laasonen, K. and Puukka, R. Effect of once-a-week training program on physical fitness and metabolic control in children with IDDM. Diabetes Care, 12, 10 (Nov-Dec 1989), 737-740.

[20] Laaksonen, D. E., Atalay, M., Niskanen, L. K., Mustonen, J., Sen, C. K., Lakka, T. A. and Uusitupa, M. I. Aerobic exercise and the lipid profile in type 1 diabetic men: a randomized controlled trial. Med Sci Sports Exerc, 32, 9 (Sep 2000), 1541-1548.

[21] Landt, K. W., Campaigne, B. N., James, F. W. and Sperling, M. A. Effects of exercise training on insulin sensitivity in adolescents with type I diabetes. Diabetes Care, 8,5 (SepOct 1985), 461-465.

[22] Maggio, A. B., Rizzoli, R. R., Marchand, L. M., Ferrari, S., Beghetti, M. and FarpourLambert, N. J. Physical activity increases bone mineral density in children with type 1 diabetes. Med Sci Sports Exerc, 44, 7 (Jul 2012), 1206-1211.

[23] Perry, T. L., Mann, J. I., Lewis-Barned, N. J., Duncan, A. W., Waldron, M. A. and Thompson, C. Lifestyle intervention in people with insulin-dependent diabetes mellitus (IDDM). Eur J Clin Nutr, 51, 11 (Nov 1997), 757-763. 
[24] Roberts, L., Jones, T. W. and Fournier, P. A. Exercise training and glycemic control in adolescents with poorly controlled type 1 diabetes mellitus. J Pediatr Endocrinol Metab, 15, 5 (May 2002), 621-627.

[25] Salem, M. A., Aboelasrar, M. A., Elbarbary, N. S., Elhilaly, R. A. and Refaat, Y. M. Is exercise a therapeutic tool for improvement of cardiovascular risk factors in adolescents with type 1 diabetes mellitus? A randomised controlled trial. Diabetology \& metabolic syndrome, 2, 1 (2010), 47.

[26] Tunar, M., Ozen, S., Goksen, D., Asar, G., Bediz, C. S. and Darcan, S. The effects of Pilates on metabolic control and physical performance in adolescents with type 1 diabetes mellitus. Journal of diabetes and its complications, 26, 4 (Jul-Aug 2012), 348-351.

[27] Wallberg-Henriksson, H. Repeated exercise regulates glucose transport capacity in skeletal muscle. Acta Physiol Scand, 127, 1 (May 1986), 39-43.

[28] Quirk, H., Blake, H., Tennyson, R., Randell, T. L. and Glazebrook, C. Physical activity interventions in children and young people with Type 1 diabetes mellitus: a systematic review with meta-analysis. Diabet Med, 31, 10 (Oct 2014), 1163-1173.

[29] Kennedy, A., Nirantharakumar, K., Chimen, M., Pang, T. T., Hemming, K., Andrews, R. C. and Narendran, P. Does exercise improve glycaemic control in type 1 diabetes? A systematic review and meta-analysis. PLoS One, 8, 3 (2013), e58861.

[30] Van Der Heijden, G. J., Wang, Z. Y. J., Chu, Z. L., Toffolo, G., Manesso, E., Sauer, P. J. J. and Sunehag, A. L. Strength exercise improves muscle mass and hepatic insulin sensitivity in obese youth. Med Sci Sports Exercise, 42, (Nov 2010), 1973-1980.

[31] Yardley, J. E., Hay, J., Abou-Setta, A. M., Marks, S. D. and McGavock, J. A systematic review and meta-analysis of exercise interventions in adults with type 1 diabetes. Diabetes Res Clin Pract, 106, 3 (Dec 2014), 393-400. 
[32] Huang, X. L., Pan, J. H., Chen, D., Chen J., Chen, F. and Hu, T. Efficacy of lifestyle interventions in patients with type 2 diabetes: A systematic review and meta-analysis. Eur $J$ Intern Med, 27, (Jan 2016), 37-47.

[33] Schuit, A. J., Schouten, E. G., Miles, T. P., Evans, W. J., Saris, W. H. M. and Kok, F. J. The effect of six months training on weight, body fatness and serum lipids in apparently healthy elderly Dutch men and women. Int J Obesity, 22, (Sept 1998), 847-853.

[34] Michaliszyn, S. F. and Faulkner, M. S. Physical activity ans sedentary behavior in adolescents with type 1 diabetes. Research in Nursing and Health, 33, 5, (Oct 2010), 441449.

[35] Cornelissen, V. A. and Smart, N. A. Exercise training for blood pressure: a systematic review and meta-analysis. J Am Heart Assoc, 2, 1 (Feb 2013), e004473.

[36] Hordern, M. D., Coombes, J. S., Cooney, L. M., Jeffriess, L., Prins, J. B. and Marwick, T. H. Effects of exercise intervention on myocardial function in type 2 diabetes. Heart, 95, 16 (Aug 2009), 1343-1349.

\section{Figure Legends}

Figure 1: Consort statement

\section{Table Legends}

Table 1: Characteristics of Included Studies

Table 2: Change in Outcome Measures Stratified by Weekly Exercise Time.

Table 3: TESTX Assessment of Study Quality of Included Studies 
Table 1. Characteristics of Included Studies

\begin{tabular}{|c|c|c|c|c|c|c|c|c|c|}
\hline Author & Participants & Wks & $\begin{array}{l}\text { Freq. } \\
(\text { Session. } \\
\left.\mathbf{W k}^{-1}\right)\end{array}$ & Intensity & $\begin{array}{l}\text { Session } \\
\text { Time (min) }\end{array}$ & Country & Participants & Intervention & Outcomes \\
\hline $\begin{array}{l}\text { Brazeau } \\
2014\end{array}$ & $18-65 \mathrm{yrs}$ & 12 & 1 & Not stated & $\begin{array}{l}60 \mathrm{PA}, 30 \\
\text { Education }\end{array}$ & Canada & $\begin{array}{l}48 \text { Patients with } \\
\text { diagnosis of } \\
\text { T1D (>12mths) } \\
\text { and report less } \\
\text { than } 150 \mathrm{~min} \text { PA } \\
\text { per week were } \\
\text { randomised into } \\
\text { control (25) and } \\
\text { Intervention } \\
(23)\end{array}$ & $\begin{array}{l}60 \text { minutes of } \\
\text { various exercise } \\
\text { including endurance, } \\
\text { flexibility and } \\
\text { resistance. } 30 \\
\text { minutes of PA } \\
\text { counselling and } \\
\text { education }\end{array}$ & $\begin{array}{l}\text { Body Weight, } \\
\text { BMI, Waist } \\
\text { circumference, } \\
\text { Physical activity } \\
\text { level (kcal), } \\
\mathrm{VO}_{2} \text { peak } \\
(\mathrm{ml} / \mathrm{kg} / \mathrm{min}), \\
\mathrm{HR}, \mathrm{SBP}, \mathrm{DBP}, \\
\mathrm{HbA} 1 \mathrm{c} \%\end{array}$ \\
\hline $\begin{array}{l}\text { Campaigne } \\
1984\end{array}$ & $5-11$ yrs & 12 & 3 & $\begin{array}{l}\text { HR }>160 \mathrm{bpm} \\
\text { Vigorous - } \\
76 \% \text { Max HR }\end{array}$ & 30 & & $\begin{array}{l}19 \text { children, } \\
\text { similar SES and } \\
\text { geographic } \\
\text { location were } \\
\text { recruited. All } \\
\text { had a diagnosis } \\
\text { of T1D } \\
\text { (>6mths), all } \\
\text { children were on } \\
\text { an insulin } \\
\text { regime. } \\
\text { Children were } \\
\text { randomly } \\
\text { assigned into } \\
\text { control (10) or } \\
\text { experimental } \\
\text { (9). }\end{array}$ & $\begin{array}{l}\text { Activity included } \\
\text { running, movement } \\
\text { to music etc. }\end{array}$ & $\begin{array}{l}\text { Peak } \mathrm{VO}_{2}, \text { Peak } \\
\text { VE, Peak HR, } \\
\text { Fasting Blood } \\
\text { glucose, } \\
\text { Hba1c\% }\end{array}$ \\
\hline
\end{tabular}




\begin{tabular}{|c|c|c|c|c|c|c|c|c|c|}
\hline $\begin{array}{l}\text { Dahl- } \\
\text { Jorgensen } \\
1980\end{array}$ & $9-15$ yrs & 20 & 2 & Not Given & 60 & Norway & $\begin{array}{l}22 \text { children who } \\
\text { had T1D were } \\
\text { enrolled. They } \\
\text { were } \\
\text { randomised into } \\
\text { a control (8) and } \\
\text { experimental } \\
\text { (14) }\end{array}$ & $\begin{array}{l}\text { No Information } \\
\text { given }\end{array}$ & HbA1c \\
\hline $\begin{array}{l}\text { D'hooge } \\
2011\end{array}$ & $10-18 \mathrm{yrs}$ & 20 & 2 & $\begin{array}{l}60 \% \text { PHR } \rightarrow \\
75 \% \text { PHR }(\text { wk } \\
12) \\
\text { Resistance } \\
20 \mathrm{RM} \rightarrow 12 \mathrm{RM} \\
(\text { wk12) }\end{array}$ & 70 & Belgium & $\begin{array}{l}16 \text { adolescents } \\
\text { with T1D (>1yr) } \\
\text { were recruited } \\
\text { into the study } \\
\text { and randomised } \\
\text { into control (8) } \\
\text { and intervention } \\
\text { (8) }\end{array}$ & $\begin{array}{l}\text { Each session } \\
\text { consisted of a warm } \\
\text { up (5min), Strength } \\
\text { training of upper and } \\
\text { lower limbs and } \\
\text { abdominal } \\
\text { muscles(30mins), } \\
\text { cycling (10mins), } \\
\text { running (10mins), } \\
\text { stepping (10mins) } \\
\text { and a warm down } \\
\text { (5mins) }\end{array}$ & $\begin{array}{l}\text { Weight, BMI, } \\
\text { waist } \\
\text { circumference, } \\
\text { Peak } \mathrm{VO}_{2} \\
(\mathrm{ml} / \mathrm{min}), \text { Peak } \\
\mathrm{HR}, \text { Blood } \\
\text { glucose, HbA1c, } \\
\text { total daily } \\
\text { insulin dose. }\end{array}$ \\
\hline $\begin{array}{l}\text { Fuchsjager } \\
\text {-Maryl } \\
2002\end{array}$ & $\begin{array}{l}\text { Adults } \\
40 \pm 10 \text { yrs }\end{array}$ & 16 & $2-3$ & $\begin{array}{l}>60 \% \text { Max } \\
\text { HR } \\
\text { Moderate } \\
\text { intensity }\end{array}$ & 50 & Austria & $\begin{array}{l}26 \text { adults were } \\
\text { recruited } 40 \pm 10 \\
\text { yrs who have } \\
\text { had T1D for } \\
20 \pm 10 \text { years. } \\
\text { They were } \\
\text { randomised into } \\
\text { an intervention } \\
\text { arm }(18) \text { and a } \\
\text { control }(8)\end{array}$ & $\begin{array}{l}\text { stationary cycling } \\
\text { training program } \\
\text { sessions } 2-3 \text { times } \\
\text { per week. (twice } \\
\text { during first } 2 \text { weeks, } \\
3 \text { per week there } \\
\text { after) }\end{array}$ & $\begin{array}{l}\text { BMI, Body } \\
\text { weight, Rest } \\
\mathrm{HR}, \mathrm{VO}_{2} \mathrm{max}, \\
\text { Lipid Panel, } \\
\text { HbA1c\%, } \\
\text { insulin dose. }\end{array}$ \\
\hline $\begin{array}{l}\text { Heyman } \\
2007\end{array}$ & $\begin{array}{l}\text { Adolescent } \\
\text { girls }\end{array}$ & 26 & 3 & $\begin{array}{l}80-90 \% \mathrm{MHR} \\
\text { reserve }\end{array}$ & $\begin{array}{l}60(x 2) \text { and } \\
120(x 1)\end{array}$ & France & $\begin{array}{l}16 \text { adolescent } \\
\text { girls with T1D } \\
\text { were recruited }\end{array}$ & $\begin{array}{l}\text { These sessions } \\
\text { consisted of a } \\
\text { combination of }\end{array}$ & $\begin{array}{l}\text { Lipid panel, } \\
\text { body mass }\end{array}$ \\
\hline
\end{tabular}




\begin{tabular}{|c|c|c|c|c|c|c|c|c|c|}
\hline & & & & & & & $\begin{array}{l}\text { and participants } \\
\text { were } \\
\text { randomised into } \\
\text { an intervention } \\
\text { group }(n=9) \text { and } \\
\text { a control }(n=7)\end{array}$ & $\begin{array}{l}\text { strength and aerobic } \\
\text { exercises at a ratio of } \\
2: 1 .\end{array}$ & \\
\hline $\begin{array}{l}\text { Huttunen } \\
1989\end{array}$ & $8-17 y r s$ & 13 & 1 & $\begin{array}{l}\text { HR }>150 \mathrm{bpm} \\
\text { Vigorous } 72 \% \\
\max \text { HR }\end{array}$ & 60 & Finland & $\begin{array}{l}34 \text { Children } \\
\text { with T1D } \\
\text { (>6mths) } \\
\text { produced } 17 \text { age } \\
\text { and sex matched } \\
\text { pairs, after drop } \\
\text { out they were } \\
\text { allocated into } \\
\text { control (16) and } \\
\text { intervention } \\
(16) \text {. }\end{array}$ & $\begin{array}{l}\text { The sessions } \\
\text { included running, } \\
\text { jogging, gymnastics } \\
\text { and other active } \\
\text { games }\end{array}$ & $\begin{array}{l}\mathrm{VO}_{2} \text { max, Blood } \\
\text { glucose, } \\
\mathrm{HbA} 1 \mathrm{c} \%\end{array}$ \\
\hline $\begin{array}{l}\text { Laaksonen } \\
2000\end{array}$ & $\begin{array}{l}20-40 \text { yrs } \\
\text { men }\end{array}$ & $\begin{array}{l}12- \\
16 \mathrm{wk}\end{array}$ & $\begin{array}{l}\mathrm{Wk} 1(3) \rightarrow \\
4-5\end{array}$ & $\begin{array}{l}\text { Wk } 120- \\
30 \text { min 50-60\% } \\
\mathrm{VO}_{2} \rightarrow 30- \\
60 \mathrm{~min} \text { at } 60- \\
80 \% \mathrm{VO}_{2} \\
\text { "Mod Intensity } \\
\text { endurance } \\
\text { training" }\end{array}$ & $20-60$ & Finland & $\begin{array}{l}42 \text { men with } \\
\text { T1D were } \\
\text { included and } \\
\text { randomized into } \\
\text { training (20) and } \\
\text { control (22) }\end{array}$ & $\begin{array}{l}\text { First week: } 20-30 \\
\text { min running at 50- } \\
60 \% \mathrm{VO}_{2} \text { mixed with } \\
\text { walking as necessary } \\
3 \text { times a week } \\
\text { training was } \\
\text { gradually increased } \\
\text { on an individual } \\
\text { basis, with a goal of } \\
30-60 \text { min running at } \\
60-80 \% \mathrm{VO}_{2} \text { peak } 4- \\
5 \text { times per week }\end{array}$ & $\begin{array}{l}\mathrm{VO}_{2} \max , \text { Daily } \\
\text { insulin dose, } \\
\mathrm{HbA} 1 \mathrm{c}, \text { Plasma } \\
\text { glucose, BMI, } \\
\text { Lipid panel }\end{array}$ \\
\hline Landt 1985 & Adolescents & 12 & 3 & $\begin{array}{l}\mathrm{HR}>160 \text { for at } \\
\text { least } 25 \mathrm{mins}\end{array}$ & 45 & USA & $\begin{array}{l}15 \text { adolescents } \\
\text { with T1D }(>1 \mathrm{yr}) \\
\text { were } \\
\text { randomised into } \\
\text { exercise (9) and } \\
\text { control (6). }\end{array}$ & $\begin{array}{l}\text { Each session } \\
\text { consisted of a } 10 \text { min } \\
\text { warm up, } 25 \text { min } \\
\text { aerobic activity to } \\
\text { music and } 10 \text { min } \\
\text { cool down. }\end{array}$ & $\begin{array}{l}\text { Weight, } \mathrm{VO}_{2} \\
\max \end{array}$ \\
\hline
\end{tabular}




\begin{tabular}{|c|c|c|c|c|c|c|c|c|c|}
\hline $\begin{array}{l}\text { Maggio } \\
2012\end{array}$ & $\begin{array}{l}\text { Children } \\
10.5 \mathrm{yrs} \pm 2.4 \\
\mathrm{yrs}\end{array}$ & 40 & 2 & HR $>140$ & 90 & Switzerland & $\begin{array}{l}27 \text { children with } \\
\text { t1D (>5mths) } \\
\text { were recruited } \\
\text { and randomised } \\
\text { into control (12) } \\
\text { and exercise } \\
(15)\end{array}$ & $\begin{array}{l}\text { Each session } \\
\text { consisted of a } 10 \text { min } \\
\text { warm up, } 10 \text { min drop } \\
\text { jump, } 60 \text { mins of } \\
\text { aerobic activity and a } \\
10 \text { min cool down. }\end{array}$ & $\begin{array}{l}\text { Body weight, } \\
\text { BMI }\end{array}$ \\
\hline Perry 1997 & $20-69 \mathrm{yrs}$ & 26 & $3-4$ & Not Given & Not given & NZ & $\begin{array}{l}61 \text { people with } \\
\text { T1D (>1yr) } \\
\text { were recruited } \\
\text { and randomised } \\
\text { into control (30) } \\
\text { and intervention } \\
\text { (31) }\end{array}$ & $\begin{array}{l}\text { Sessions included } \\
\text { cycling, walking, } \\
\text { running and weight } \\
\text { training. } \\
\text { Patient were given } \\
\text { dietary advice. }\end{array}$ & $\begin{array}{l}\text { Weight, SBP, } \\
\text { DBP,HbA1c, } \\
\text { lipid Panel, } \mathrm{VO}_{2} \\
\max (1 / \mathrm{min}) \text {, rest } \\
\mathrm{HR}\end{array}$ \\
\hline $\begin{array}{l}\text { Roberts } \\
2002\end{array}$ & $14 \pm 1.2 \mathrm{yrs}$ & 12 & 3 & $\mathrm{HR}>160$ & 45 & Aust & $\begin{array}{l}24 \text { adolescents } \\
\text { with T1D } \\
\text { (5yrs } \pm 3.1 \mathrm{yrs}) \text { of } \\
\text { a similar SES } \\
\text { background } \\
\text { were selected } \\
\text { and allocated } \\
\text { into control (12) } \\
\text { and intervention } \\
\text { (12) }\end{array}$ & $\begin{array}{l}\text { Sessions had an } \\
\text { aerobic to anaerobic } \\
\text { ratio of } 7: 3\end{array}$ & $\begin{array}{l}\text { Body mass, } \\
\text { BMI }\end{array}$ \\
\hline $\begin{array}{l}\text { Salem } \\
2010\end{array}$ & $12-18 \mathrm{yrs}$ & 26 & $\begin{array}{l}\text { Group B- } \\
1 \\
\text { Group C- } \\
3\end{array}$ & $\begin{array}{l}\text { THRR }=220- \\
\text { age in years } \\
\times(65-85 \%)\end{array}$ & & Egypt & $\begin{array}{l}196 \text { adolescents } \\
\text { with T1D } \\
\text { (>3yrs) and } \\
\text { HbA1c }>7.5 \% \\
\text { for 6mths were } \\
\text { allocated into } \\
\text { control (48), and } \\
\text { two intervention } \\
\text { groups, once per } \\
\text { week (75) and }\end{array}$ & $\begin{array}{l}\text { Each session lasted } \\
\text { for } 30 \text { minutes and } \\
\text { consisted of warm up } \\
\text { (5), training period } \\
\text { (20) and warm down } \\
\text { (20). Activities } \\
\text { included cycling, } \\
\text { treadmill and } \\
\text { strength and } \\
\text { resistance exercises }\end{array}$ & $\begin{array}{l}\text { SBP, waist } \\
\text { circumference, } \\
\text { Insulin dose, } \\
\text { Hypoglycaemia } \\
\text { attacks, HbA1c, } \\
\text { lipid profile }\end{array}$ \\
\hline
\end{tabular}




\begin{tabular}{|c|c|c|c|c|c|c|c|c|c|}
\hline & & & & & & & $\begin{array}{l}\text { three times per } \\
\text { week (73). }\end{array}$ & & \\
\hline Tunar 2012 & $14.2 \pm 2 \mathrm{yrs}$ & 12 & 3 & Not given & 45 & Turkey & $\begin{array}{l}31 \text { Children } \\
\text { with a diagnosis } \\
\text { of T1D were } \\
\text { included and } \\
\text { randomised into } \\
\text { control (14) and } \\
\text { intervention (17) }\end{array}$ & Mat Based Pilates & $\begin{array}{l}\text { HbA1c, Daily } \\
\text { insulin dose, } \\
\text { Lipid profile, } \\
\text { Peak Power (w) }\end{array}$ \\
\hline $\begin{array}{l}\text { Wallberg- } \\
\text { Henriksson } \\
1986\end{array}$ & $\begin{array}{l}25-45 \text { yrs } \\
\text { Women }\end{array}$ & 20 & 7 & $\begin{array}{l}1^{\text {st }} \text { Month- 60- } \\
70 \% \mathrm{VO}_{2} \mathrm{max} \\
\rightarrow 70-80 \% \\
\mathrm{VO}_{2} \mathrm{max} \\
\text { "high intensity } \\
\text { cycling" }\end{array}$ & 20 & Sweden & $\begin{array}{l}21 \text { Female T1D } \\
\text { ( >5yrs) patients } \\
\text { were recruited } \\
\text { and were } \\
\text { randomised into } \\
\text { control (10) and } \\
\text { training (11) }\end{array}$ & $\begin{array}{l}\text { Each session had a } 5 \\
\text { min warm up and a } \\
\text { 15-minute-high } \\
\text { intensity cycling }\end{array}$ & $\begin{array}{l}\text { Lipid profile, } \\
\mathrm{VO}_{2} \max .\end{array}$ \\
\hline
\end{tabular}

Key: Aust - Australia; BMI - body mass index; DBP - diastolic blood pressure; HR - heart rate; MHR - maximum heart rate; NZ - New Zealand; PA physical activity; PHR - peak heart rate; RM - repetition maximum; SBP - systolic blood pressure; SES - social economic status; T1D - type 1 diabetes; THRR - training heart rate range; VE - minute ventilation; wks - weeks; yrs - years. 
Table 2. Change in Outcome Measures Stratified by Weekly Exercise Time.

\begin{tabular}{|c|c|c|c|c|c|c|c|c|c|}
\hline & \multicolumn{3}{|c|}{$<100$ mins per week } & \multicolumn{3}{|c|}{ 100-150 mins/week } & \multicolumn{3}{|c|}{$>150 \mathrm{~min} /$ week } \\
\hline & $\begin{array}{l}\text { Mean } \\
\text { Difference } \\
(95 \% \mathrm{CI})\end{array}$ & $\begin{array}{l}\text { No. of } \\
\text { Study } \\
\text { groups } \\
\text { (participants } \\
\text { ) }\end{array}$ & $\mathrm{P}$ value & $\begin{array}{l}\text { Mean Difference } \\
(95 \% \mathrm{CI})\end{array}$ & $\begin{array}{l}\text { No. of } \\
\text { Study } \\
\text { Groups } \\
\text { (Participant } \\
\text { s) }\end{array}$ & $\mathrm{P}$ value & $\begin{array}{l}\text { Mean Difference } \\
(95 \% \text { CI })\end{array}$ & $\begin{array}{l}\text { No. of } \\
\text { Study } \\
\text { Groups } \\
\text { (Participant } \\
\text { s) }\end{array}$ & $\begin{array}{l}\mathrm{P} \\
\text { value }\end{array}$ \\
\hline $\operatorname{HbA1C}(\%)$ & $-0.13[-0.31,0.06]$ & $6(287)$ & 0.19 & $0.15[0.03,0.28]$ & $4(92)$ & 0.02 & $\begin{array}{l}-0.40 \\
0.13]\end{array} \quad[-0.67, \quad-$ & $1(42)$ & 0.003 \\
\hline $\begin{array}{l}\text { Blood Glucose } \\
\left(\mathrm{mmol} . \mathrm{L}^{-1}\right) .\end{array}$ & $-1.36[-5.26,2.54]$ & $2(51)$ & 0.50 & $\begin{array}{l}-0.61 \quad[-0.97, \quad- \\
0.25]\end{array}$ & $1(16)$ & 0.0009 & $-0.20[-2.46,2.06]$ & $1(42)$ & 0.86 \\
\hline $\begin{array}{l}\text { Insulin Dose. } \\
\left(\mathrm{IU} / \mathrm{kg} \cdot \mathrm{d}^{-1}\right)\end{array}$ & $-0.38[-0.78,0.02]$ & $2(196)$ & 0.06 & $\begin{array}{lll}-0.11 & {[-0.16,} & - \\
0.06] & \end{array}$ & $3(70)$ & .00001 & $0.01[0.00,0.02]$ & $1(42)$ & 0.04 \\
\hline $\mathrm{BMI}\left(\mathrm{Kg} \cdot \mathrm{m}^{-2}\right)$ & $\left.\begin{array}{lll}-0.30 & {[-0.58,} & - \\
0.02\end{array}\right] \quad-$ & $1(43)$ & 0.04 & $-0.07[-0.51,0.36]$ & $3(63$ & 0.74 & $\begin{array}{l}-0.15 \quad[-0.28, \\
0.03]\end{array}$ & $2(69)$ & 0.02 \\
\hline $\begin{array}{ll}\text { Body } & \text { Mass } \\
(\mathrm{Kg}) & \\
\end{array}$ & $0.09[-2.19,2.37]$ & $2(62)$ & 0.94 & $-1.21[-3.71,1.29]$ & $3(63)$ & 0.34 & $0.90[-0.41,2.21]$ & $2(43)$ & 0.18 \\
\hline $\begin{array}{l}\text { Peak } \mathrm{VO}_{2} \\
\left(\mathrm{mlO}_{2} \cdot \mathrm{kg}^{-}\right. \\
\left.{ }^{1} \cdot \mathrm{min}^{-1}\right)\end{array}$ & $2.32[0.64,4.00]$ & $3(89)$ & 0.007 & $2.94[1.15,4.72]$ & $3(88)$ & 0.001 & $1.30[-1.21,3.81]$ & $1(42)$ & 0.31 \\
\hline $\begin{array}{l}\text { LDL } \\
\left(\mathrm{mmol.L} \mathrm{L}^{-1}\right)\end{array}$ & $\begin{array}{l}-0.43 \\
0.22]\end{array} \quad[-0.64, \quad-$ & $2(196)$ & $<0.0001$ & $\begin{array}{l}-0.17 \quad[-0.27, \quad- \\
0.07]\end{array}$ & $3(67)$ & 0.006 & $-0.09[-0.29,0.11]$ & $2(57)$ & 0.38 \\
\hline $\begin{array}{l}\mathrm{HDL} \\
\left(\mathrm{mmol.L} \mathrm{L}^{-1}\right)\end{array}$ & $0.30[0.26,0.34]$ & $2(196)$ & $<0.00001$ & $\begin{array}{l}-0.06 \\
0.03]\end{array} \quad[-0.09, \quad-$ & $3(67)$ & 0.0003 & $-0.04[-0.10,0.03]$ & $2(58)$ & 0.26 \\
\hline $\begin{array}{l}\text { TGD } \\
\left(\mathrm{mmol} \cdot \mathrm{L}^{-1}\right)\end{array}$ & $\begin{array}{l}-0.34 \\
0.07]\end{array} \quad\left[\begin{array}{lll}-0.61, & -\end{array}\right.$ & $2(196)$ & 0.01 & $-0.08[-0.29,0.12]$ & $3(67)$ & 0.43 & $-0.14[-0.40,0.12]$ & $2(58)$ & 0.30 \\
\hline
\end{tabular}

Key

LDL - Low density lipoprotein, HDL - High density lipoprotein, TGD - Triglyceride 
Table 3. TESTex Assessment of Study Quality of Included Studies

\begin{tabular}{|c|c|c|c|c|c|c|c|c|c|c|c|c|c|}
\hline Study & $\begin{array}{l}\text { Eligibili } \\
\text { ty } \\
\text { Criteria } \\
\text { specifie } \\
\text { d }\end{array}$ & $\begin{array}{l}\text { Randoml } \\
\text { y } \\
\text { allocated } \\
\text { participan } \\
\text { ts }\end{array}$ & $\begin{array}{l}\text { Allocati } \\
\text { on } \\
\text { conceale } \\
\text { d }\end{array}$ & $\begin{array}{l}\text { Groups } \\
\text { Similar } \\
\text { at } \\
\text { baseline }\end{array}$ & $\begin{array}{c}\text { Assessors } \\
\text { blinded }\end{array}$ & $\begin{array}{c}\text { Outcome } \\
\text { Measures } \\
\text { assessed } \\
>85 \% \\
\text { of } \\
\text { participants } \\
\#\end{array}$ & $\begin{array}{l}\text { Intention } \\
\text { to treat } \\
\text { analysis }\end{array}$ & $\begin{array}{l}\text { Reporting of } \\
\text { between } \\
\text { group } \\
\text { statistical } \\
\text { comparisons }\end{array}$ & $\begin{array}{c}\text { Point } \\
\text { measures } \\
\& \\
\text { measures } \\
\text { of } \\
\text { variability } \\
\text { reported* }\end{array}$ & $\begin{array}{c}\text { Activity } \\
\text { Monitoring } \\
\text { in Control } \\
\text { Group }\end{array}$ & $\begin{array}{l}\text { Relative } \\
\text { Exercise } \\
\text { Intensity } \\
\text { Review }\end{array}$ & $\begin{array}{c}\text { Exercise } \\
\text { Volume \& } \\
\text { Energy } \\
\text { Expended }\end{array}$ & $\begin{array}{c}\text { Overall } \\
\text { TESTEx }\end{array}$ \\
\hline Brazeau 2014 & YES & YES & $\mathrm{NO}$ & YES & Unclear & YES (2) & $\mathrm{NO}$ & YES (2) & YES & NO & NO & YES & 9 \\
\hline $\begin{array}{c}\text { Campaigne } \\
1984\end{array}$ & YES & YES & $\mathrm{NO}$ & YES & Unclear & YES (1) & $\mathrm{NO}$ & YES (2) & YES & NO & $\mathrm{NO}$ & YES & 8 \\
\hline $\begin{array}{c}\text { Dahl- } \\
\text { Jorgensen } \\
1980\end{array}$ & YES & NO & NO & Unclear & $\mathrm{NO}$ & YES (1) & NO & YES (2) & YES & NO & NO & NO & 5 \\
\hline $\begin{array}{c}\text { D'hooge } \\
2011\end{array}$ & YES & YES & NO & YES & Unclear & ES (2) & NO & YES (2) & YES & NO & YES & YES & 10 \\
\hline $\begin{array}{l}\text { Fuchsjager- } \\
\text { maryl } 2002\end{array}$ & YES & NO & Unclear & YES & Unclear & (3) & NO & YES (2) & YES & NO & YES & YES & 10 \\
\hline $\begin{array}{c}\text { Heyman } \\
2007\end{array}$ & YES & YES & YES & YES & & YES (2) & NO & YES (2) & YES & NO & YES & YES & 10 \\
\hline Huttunen & YES & NO & Unclear & YE & Unclear & YES (2) & NO & YES (2) & YES & NO & NO & YES & 8 \\
\hline
\end{tabular}


1989

\begin{tabular}{|c|c|c|c|c|c|c|c|c|c|c|c|c|c|}
\hline $\begin{array}{c}\text { Laaksonen } \\
2000\end{array}$ & YES & YES & YES & YES & $\mathrm{NO}$ & YES (2) & $\mathrm{NO}$ & YES (2) & YES & NO & YES & YES & 11 \\
\hline Landt 1985 & $\mathrm{NO}$ & YES & YES & YES & Unclear & YES (2) & $\mathrm{NO}$ & YES (2) & YES & & NO & YES & 9 \\
\hline Maggio 2012 & YES & YES & YES & YES & NO & YES ( 3 ) & NO & YES (2) & & $\mathrm{NC}$ & $\mathrm{NO}$ & YES & 11 \\
\hline Perry 1997 & YES & YES & YES & YES & NO & YES (3) & $\mathrm{NO}$ & YES (2) & YES & NO & NO & $\mathrm{NO}$ & 10 \\
\hline Roberts 2002 & YES & YES & YES & YES & NO & YES (2) & NO & YES & YES & NO & NO & YES & 10 \\
\hline Salem 2010 & YES & YES & YES & YES & Unclear & NO (1) & $\mathrm{NO}$ & YES (2) & NO & NO & YES & YES & 9 \\
\hline Tunar 2012 & YES & YES & YES & YES & Unclear & YES (1) & & YES (2) & YES & NO & $\mathrm{NO}$ & $\mathrm{NO}$ & 8 \\
\hline $\begin{array}{l}\text { Wallberg- } \\
\text { Henriksson } \\
1986\end{array}$ & YES & YES & YES & YES & Unclear & I & NO & YES (2) & YES & NO & YES & YES & 10 \\
\hline Totals & 14 & 12 & 9 & 14 & & & 0 & 15 & 14 & 0 & 6 & 12 & Median \\
\hline
\end{tabular}




\section{Highlights}

$>$ Meta-analysis investigating exercise training in type 1 diabetes

Exercise reduced daily insulin, $\mathrm{BMI}$, peak $\mathrm{VO}_{2}$ and resting heart rate

Exercise also reduced resting systolic blood pressure, LDL and triglycerides

No effect on $\mathrm{HbA1C} \%$, Fasting Blood Glucose, body mass or HDL

This could stimulate development of novel treatment regimes for type 1 diabetes 
Figure 1. Consort Statement
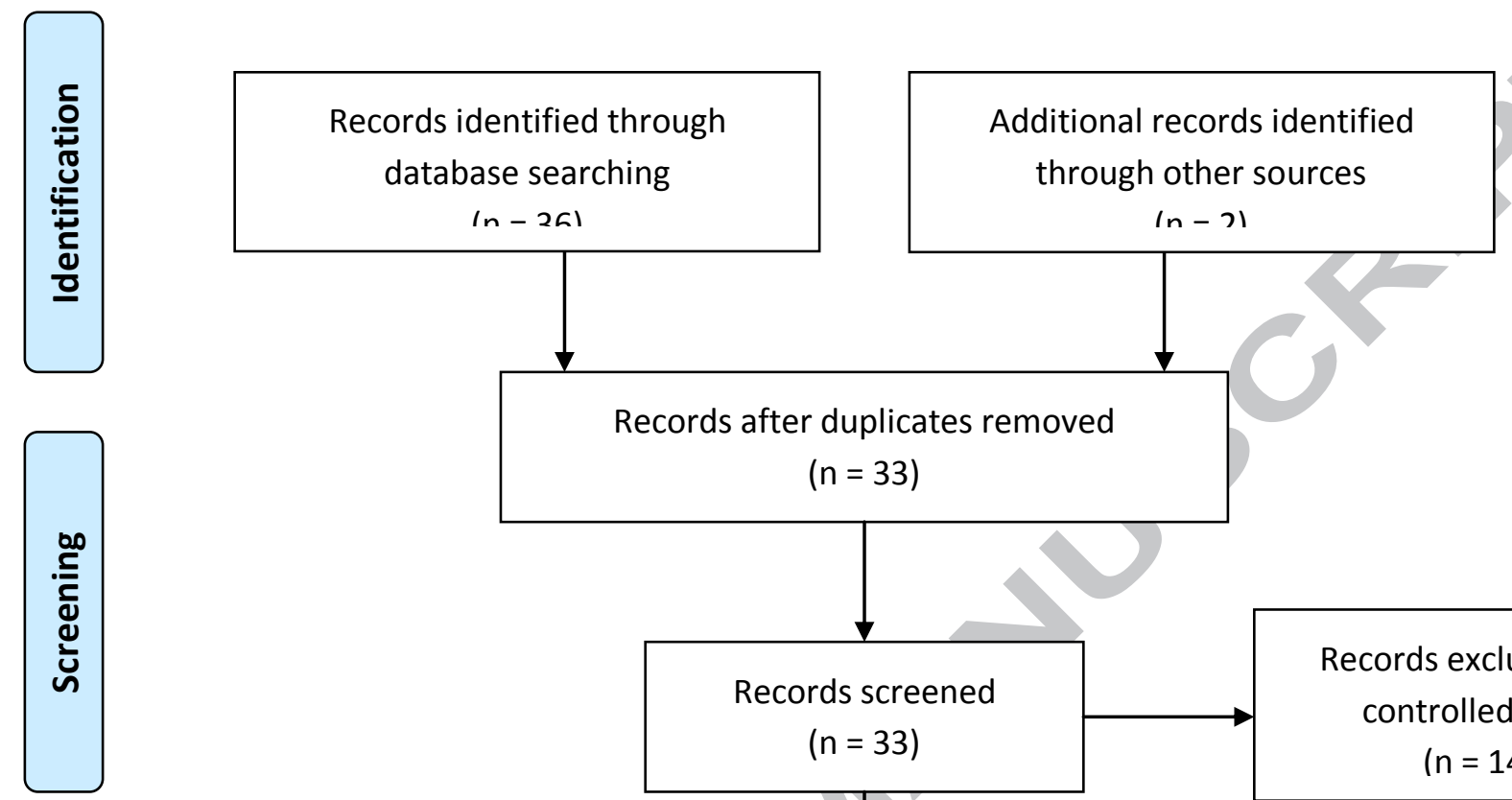

Records after duplicates removed



Records excluded not controlled trials $(n=14)$

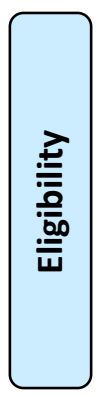

Full-text articles excluded,

Full-text articles assessed for eligibility $\ln =10$ ) with reasons $\ln =11$

Studies included in quantitative synthesis (meta-analysis) $(n=15)$ 